\title{
USING SOCIAL MEDIA AS A LEARNING MEDIA OF FOREIGN LANGUAGE STUDENTS IN HIGHER EDUCATION
}

\author{
Agung Rinaldy Malik \\ Pendidikan Bahasa Universitas Negeri Jakarta, Indonesia \\ agungrinaldym_pb@mahasiswa.unj.ac.id \\ Muhammad Nur Ashar Asnur \\ Pendidikan Bahasa Jerman, Universitas Negeri Jakarta, Indonesia \\ ashar@unj.ac.id
}

\begin{abstract}
Foreign language is an important component of someone in facing the era of Industry 4.0. The development of Information and Communication Technology (ICT) will have an impact on the creation of a learning media innovation that will facilitate users in the learning process in higher education. Likewise in foreign language learning. Onlinebased learning has been designed in such a way as to increase learning knowledge and motivation. This study uses a qualitative approach with the survey method. Data and Sources of data in this study are students of foreign language study programs at universities in Indonesia. The results of the study show that students generally always use smartphones and use social media in all their activities. Students use a lot of social media in exploring vocabulary and increasing vocabulary mastery, learning as well as building networks for native speakers (Muttersprachler), and making social media a means of learning by accessing foreign-language songs and interesting media in student foreign language learning. Thus social media can be one of the means of education for students which ends in improving foreign language skills.
\end{abstract}

Keywords: Social Media, Learning Media, Learning Foreign Languages, Higher Education

\section{INTRODUCTION}

Language is the main component in interacting and communicating. Through language, humans can interact and establish good communication with other humans. As a communication tool, language is used by every human being to convey opinions, thoughts and feelings to others, both oral and written. By not using language, of course someone will experience difficulties in interacting with each other. In addition, language can be used by people to find out how broad their thinking horizons are to know their world because language is also a measure of the size of one's knowledge.

Along with the development of technology, information and communication. Indonesian society is expected to continue developing language competencies in this case foreign languages. In Government Regulation No. 57 of 2014 concerning the development, guidance and protection of languages. Article 22 in 
BAHTERA: Jurnal Pendidikan Bahasa dan Sastra, Volume 18 Nomor 2 Juli 2019 http://journal.unj.ac.id/unj/index.php/bahtera/

P-ISSN : 0853-2710

E-ISSN : 2540-8968

facilitating the improvement of foreign language competence for Indonesian citizens is carried out to accelerate and expand the mastery of science, technology, and art; and improve capabilities and expand international communication. Therefore, several foreign languages have been taught in schools both junior high and high school and are equal.

The use of innovative and creative media is also expected to be able to stimulate learners to be more enthusiastic in the process of language learning (Yanti, Amalia, \& Nawawi, 2018). The level of success of students in learning can also be seen from the method or model applied by the teacher or educator in the classroom (Mukuan, 2016:75). The expectation of learning is more varied, making students more entertained and pleasant. By that, it is necessary to make a learning method that is able to answer the challenges of the present era in the era of the civil revolution 4.0 in order to be able to motivate students to learn more (Putrawangsa \& Hasanah, 2018: 48).

The United Nations Educational, Scientific and Cultural Organization (UNESCO) as an organization of education, science and culture of the United Nations (UN) has ensured that all developed and developing countries have the best educational facilities needed to prepare young people to play a full role in modern society and to contribute to the development of knowledge. The strategy used is to integrate the use of Information and communication technology (ICT) in learning. The approach supports active and creative teachers who are able to stimulate and manage learning of students, integrating a range of preferred learning styles and uses of ICT in achieving their goals (Noor-Ul-Amin, 2013:67).

The application of ICT strategies in the learning process is expected to be a solution that is both solution for students and lecturers in learning and developing critical thinking skills, generalist competencies, decision making, handling of dynamic situations, and communicating effectively. UNESCO explained that the use of ICT as a learning tool will certainly provide at least some benefits. One of them is ICT Literacy. At least, the use of ICT in learning will increase the knowledge of students and lecturers in using technological tools in learning. There is an emphasis on ICT literacy and basic skills (Kraut, 2013: 89). Learning is expected to be able to improve basic skills and ICT or digital Literacy for both students and lecturers. The use of information / communication technology that has been so sophisticated to support the success of updating learning strategies and techniques (Alfawareh \& Jusoh, 2017) ICT easily and cheaply has eliminated the boundaries of space, time and place that have so far limited the world of education(Nasution, 2016).

The development of social media is also inseparable in all current community activities. Indonesian society cannot be separated from online media (internet) especially among teenagers (Cahyono, 2016; Putrawangsa \& Hasanah, 2018). Those who are almost daily occupied with the use of social media that starts unstoppable. The social media that is being loved by the people of Indonesia has provided so many benefits ranging from learning facilities, looking for old friends, to producing rupiah coffers. Some social media that have become the trend of today's young people in Indonesia are Facebook, Youtube, Twitter and 
E-ISSN : 2540-8968

Instagram. Until the message exchange application like Whatsapp, Line, Wechat, BeeTalk, Tantan, and Tinder.

The Indonesian internet service provider association (APJII) report explains that the level of internet users in Indonesia continues to experience a very significant increase. Data shows that in 2017 shows that internet users in Indonesia reached 143.26 million users of Indonesia's total population of 262 million. The percentage of internet users in 2017 reached $54.68 \%$ with the composition of users aged 19-34 reaching a percentage of $49.52 \%$. The rapid development of the online world has begun to be glimpsed as a golden opportunity as well as a challenge by various groups including educational activists.

Social media has enough means and access to develop language skills. Several studies on social media have been carried out (Devi, Gouthami, \& Lakshmi, 2019; Saleh, Saud, \& Asnur, 2018; Griesemer, 2013; Mutalib, Abd Halim, N, \& Yahaya, 2012). Each of these studies only focuses on the learning process in general. This research takes part specifically specifically foreign language learning at the tertiary level in Indonesia. This is based on the fact that social media users in Indonesia are including massive users and continue to increase and there are many social media accounts both Facebook, Youtube and Instagram that can be accessed anywhere at any time. Therefore, based on the background stated above, the researcher will further discuss how the use of social media in student foreign language learning in Indonesia.

\section{METHOD}

This study uses a qualitative approach. The method used in this study is the survey method. The instrument used in this study is a questionnaire containing questions about how much the impact of using social media in learning foreign languages. The data sources in this study are all students in Indonesia. The data of this study are 52 foreign language education students in universities spread across various universities / colleges / equivalent in Indonesia.

\section{RESULTS AND DISCUSSION}

Based on the results of the study obtained data that there are several things related to the impact of using social media in foreign language learning in higher education. The results of this study obtained three important points, namely the intensity of smartphone use, foreign language learning, and social media in learning foreign languages. The results of this study are further described as follows.

1. Use of smartphone

a. Frequency of use of Student Smartphones 


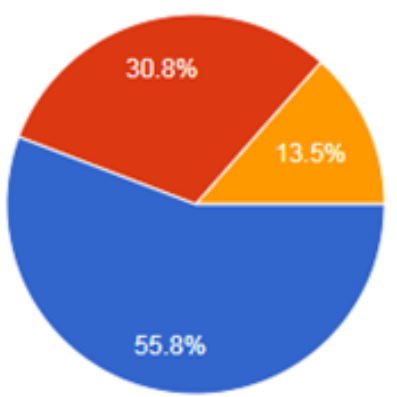

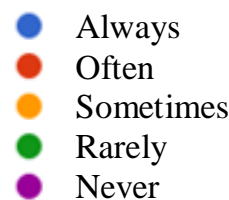

- Never

Figure 1. Frequency of Students Bringing Smartphones

The data in figure 1. above shows that the frequency of students (always) carrying smartphones in their activities is 29 respondents with a percentage $(55.8 \%)$. In addition, 16 respondents (29.4\%) stated (often) carrying smartphones. Respondents were (sometimes) as many as 7 b. Smartphone as a Language Learning Media respondents (13.7). None of the students rarely carried a smartphone anywhere in their activities. The results of this survey show that students generally bring their smartphones every day. Through Smartphones, students can easily overcome several problems every day.
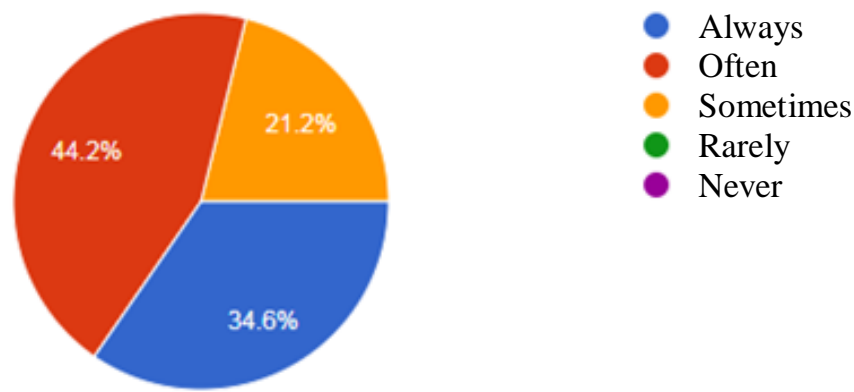

Figure 2. Students Learning Language Using Smartphones
The data in Figure 2. shows that the frequency of students (often) using smartphones in language learning is 23 respondents $(44.2 \%)$. Respondents who stated that they often use smartphones in language learning were 18 respondents (34.6\%). Students who sometimes use smartphones in language learning are 11 respondents (21.2\%), Rarely and never even a student who does not use a smartphone in learning languages. The results of this survey show students realize that smartphones also have a role in the process of language learning. The difficulties they sometimes get in the learning process, can be overcome by using a smartphone. Thus, they consider that in the process of learning the language, it is very necessary to be supported by a smartphone device.

2. Foreign Language Learning

Students learning foreign languages are required to master the material they have learned well and one proof that the student has mastered it is through productive skills both orally and in writing. The frequency of students practicing their language skills can be seen in the following diagram 


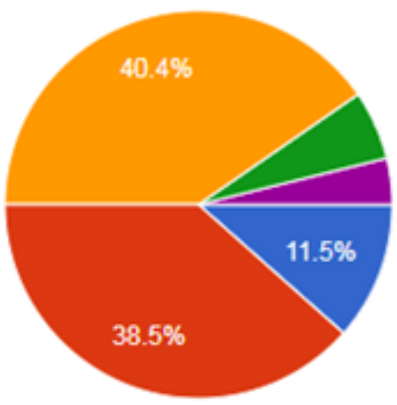

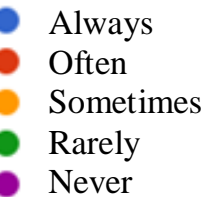

Figure 3. Students Practice Language Skills

In Figure 3. shows that the frequency of students (sometimes) practicing language whenever and wherever as many as 21 respondents (40.4\%) Respondents who stated often used and practiced the language as many as 20 students (38.5\%), sometimes as many as 6 respondents $(11.5 \%)$, rarely as many as $3(5.3 \%)$, and no respondent who never used social media in learning and practicing language wherever and whenever. The results of this survey illustrate that sometimes students practice language to improve their productive skills. Through the practice of language, they can deepen their mastery of foreign languages and at the same time train their sensitivity to the language they learn.

3. Social media in Learning Foreign Languages

a. Types of Social Media Offered

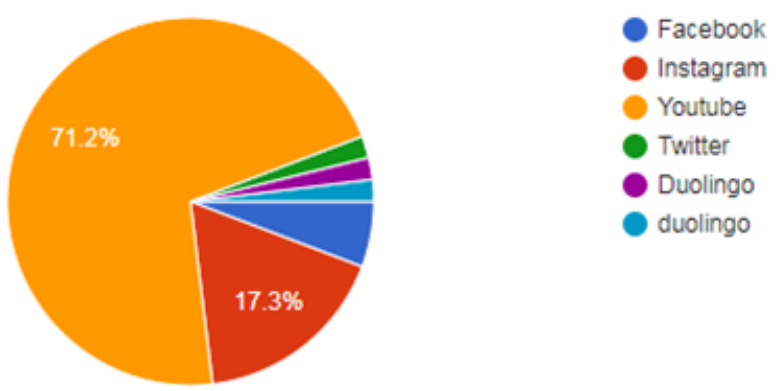

Figure 4. Percentage of social media users

Based on the data obtained in figure 4 the number of students using youtube social media in learning was 37 respondents with a percentage $(71.2 \%)$. Besides that Instagram social media is also widely used in learning. A total of 9 (17.3) respondents used Instagram in learning. In addition, Facebook followed 3 respondents, Duolingo 2 respondents, and Twitter 1 respondent.
These results can be interpreted that the most popular type of social media in learning foreign languages is Youtube. This social media offers features in the form of videos that can stimulate the senses of sight and hearing of learners so that the percentage of understanding of foreign languages studied also increases.

b. Vocabulary Pool 

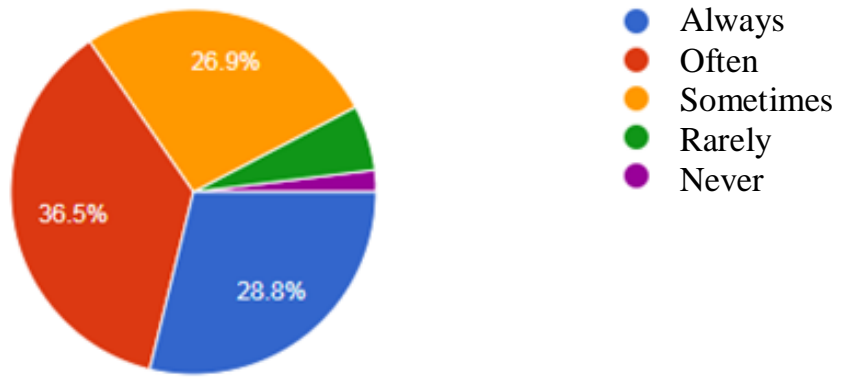

Figure 5. Social Media in Exploring Vocabulary

Based on the data obtained in Figure 5. It shows that the percentage of students who often use social media in searching for new vocabulary is 21 respondents $(36.5 \%), 17$ respondents $(28.8 \%), \quad 11$ respondents $(26.5 \%)$ sometimes- sometimes using social media in finding new vocabulary. 2 respondents and 1 respondent who rarely use social media in exploring vocabulary in language learning.

Vocabulary is an integral part of learning foreign languages. The results

c. Tandem Partner of this survey illustrate that students as language learners often use social media as their vocabulary pool. From the large number of vocabulary in the media content, they can take several parts of the vocabulary that they think are still foreign, need to be known, and in accordance with the context of their use. Thus, social media certainly builds learners' curiosity about existing vocabulary and as one solution they learn new vocabulary.
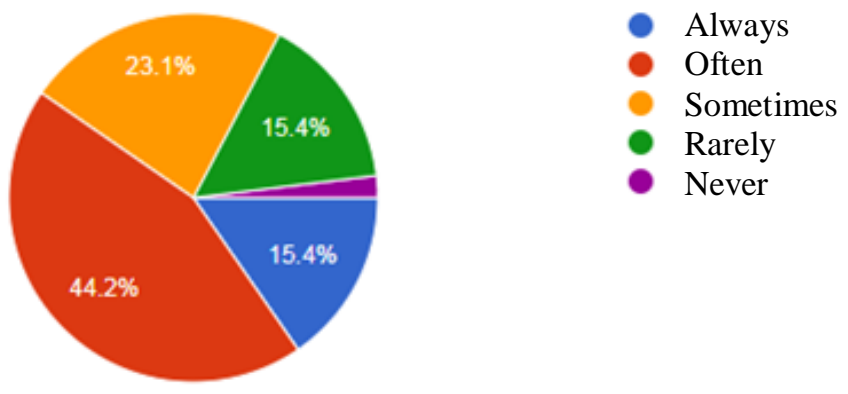

- Rarely

The data in figure 6 shows that students often use social media in communicating with native speakers (Muttersprachler). A total of 23 respondents $(44.2 \%)$ often use social media in interacting and trying to communicate with strangers. 12 Respondents (23.1\%) sometimes communicate with strangers. 8 respondents $(15.4 \%)$ who always communicate using social media in interacting with strangers. $8(15.4 \%)$ are also rare and 1 respondent has never communicated with foreigners using social media.

In order to train students' foreign language skills, they strive to be able to communicate with native speakers (Muttersprachler). Social media makes it easy to build networks to various 
parts of the world to establish communication with one another.

features are important reasons so Tandem partners offered in social media d. Foreign Language Songs

students use social media in learning foreign languages.
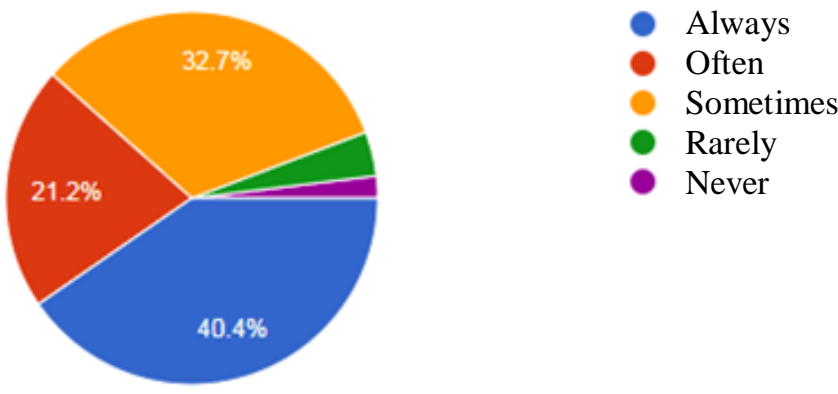

Figure 7. Searching for Foreign Language Songs on Social Media

Data obtained that students always use social media in finding foreign language songs as a source of learning. The percentage shows that there are $19(40.4 \%)$ respondents who always use social media in searching for foreign-language songs. 15 respondents (32.7) of them sometimes access social media in searching for foreign language songs. 14 respondents $(21.2 \%)$ often used. 3 rare respondents and 1 student who never used social media in searching for foreign language songs on social media.

e. Language Learning Media

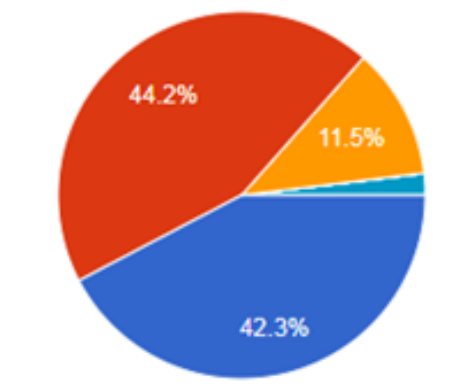

There have been many types of songs that are in line with the current era and are liked by students in foreign languages easily found on social media. Through the song search feature, students can find the type of song that will be their source of learning. In addition, the skill to give comments to the songs offered is one of the added values for students to practice their expertise in foreign languages. In addition, they can also cover the same song by recording themselves to practice the skill of reciting the song and uploading it on social media.

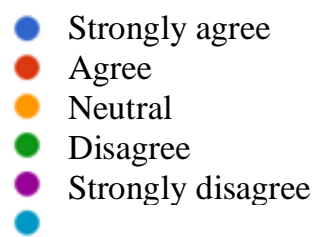

Figure 8. Social media as an interesting medium for learning languages

From the frequency data in Figure 8. shows that students who agree say that using social media makes it easier to learn foreign languages as many as 23 respondents (44.2\%). Respondents who stated strongly agreed to use and practice language were 22 respondents (\%), neutral as many as 6 
E-ISSN : 2540-8968

respondents (11.5\%), and no respondents $(0 \%)$ who disagreed and strongly disagreed that using social media made it easier in learn a language. The results above illustrate that the ease of social media has a positive influence on students in doing

f. Increasing Foreign Language Skills various things, especially as a means of learning foreign languages. Students can take advantage of various types of famous social media and can be accessed via a smartphone. The ease then leads to their interest in learning a foreign language.

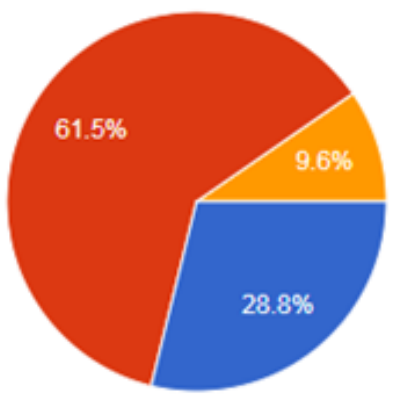

Strongly agree
Agree
Neutral
Disagree
- Strongly disagree

Figure 9. Increasing Foreign Language Skills

The survey results in figure 9 show that as many as 32 students (agreed) $32(\%)$ said that using social media made their foreign language skills increase. Respondents who stated strongly agreed were 15 (28.8\%), neutral as many as 5 respondents (9.6\%), and there were no respondents who did not disagree and strongly disagree that using social media can improve my language skills.

This increase in foreign language skills can be influenced by two factors. Factors that become the findings of researchers are factors that come from the personal self of students as learners of foreign languages, and factors that come from outside the student's own personal. The first factor is meant that students do have a high curiosity about the foreign languages they learn, so most of them try to improve their abilities by utilizing social media which has a variety of interesting features. This certainly has a significant effect on improving their foreign language skills. The second factor is the use of social media as an alternative used by foreign language teachers in universities to foster student learning motivation. Changes in behavior in a positive direction arise when appropriate treatment is given to students in accordance with the context of the times. Through the stimulus, students as foreign language learners directly apply their language knowledge through social media as well as a place to express themselves.

\section{CONCLUSION}

Based on the findings of respondents consisting of foreign language students in higher education, it can be said that social media has an impact in improving the foreign language of students. 52 respondents were dominated by the Institution of Education Personnel Lambaga (LPTK) in Indonesia, including Makassar State University (UNM), Surabaya State University (Unesa), Jakarta State University (UNJ), and Indonesian Education University (UPI). The rest came from the Muhammadiyah 
E-ISSN : 2540-8968

University campus, the Islamic State University (UIN), Samratulangi University Manado, and the Papua Paradise University.

Findings data show that students always carry smartphones at all times in all their activities. Almost all students always use smartphones and use social media. Based on the findings obtained, students assume that the use of social media can improve their skills in the process of learning foreign languages. Using social media makes it easier to access it anytime and anywhere. Using social media makes students able to access whatever they want in supporting language learning.

Social media also has an influence on increasing understanding of student vocabulary. Some students directly follow language learning content on social media. The content can be in the form of study groups, vocabulary material from foreign language institutions, foreign language online news contained in the link, to daily foreign language vocabulary on accounts learning foreign languages.

In the aspect of foreign language productive skills, the tandem partner features available on social media will also train intensively foreign-language students. Networking with native speakers will certainly motivate students to understand the language of native speakers (Muttersprachler). Because language without being trained will disappear and practicing with native speakers will be more meaningful (Wael, Asnur, \& Ibrahim, 2018; Saud, Saleh, \& Asnur, 2018). In addition, the social media currently used by most students is Youtube. This social media is very popular and has a variety of positive content, especially in learning foreign languages. Features of videos, songs, and comments can be used by students learning foreign languages. This is in line with research (Yusri, Rosida, Jufri, \& R, 2018) that Youtube has an effect on improving the results of learning English. Youtube is widely used in searching for language learning videos that can stimulate someone to learn languages. This application is the most popular application for learners because it can improve their language skills. Students access many foreign language songs on social media. This is in line with previous research revealed by (Ratminingsih, 2016) that audio-based media songs can increase student motivation in learning languages. The results of the study prove that audio media is effective in increasing one's competence in learning foreign languages. All the features presented in social media in principle have had a positive impact as well as interestingly applied to students' foreign language learning in college. The facilities provided, in accordance with the times, grow students' creativity, the arena of self-actualization towards mastering foreign languages, building networks, and alternative solutions for foreign language learning in universities.

\section{REFERENCES}

Alfawareh, H. M., \& Jusoh, S. (2017). The Use and Effects of Smartphones in Higher Education. International Journal of Interactive Mobile Technologies (IJIM), 11(6), 103. https://doi.org/10.3991/ijim.v11i6. 7453

Cahyono, A. S. (2016). Pengaruh Media Sosial Terhadap Perubahan Sosial Masyarakat di Indonesia. Jurnal Publiciana, 9(1), 140-157.

Devi, K. S., Gouthami, E., \& Lakshmi, V. V. (2019). Role of Social Media in Teaching - Learning Process. 
E-ISSN : 2540-8968

Journal of Emerging Technologies and Innovative Research (JETIR), 6(1), 96-103.

Griesemer, J. A. (2013). Using Social Media to Enhance Student Learning. Quality Approaches in Higher Education, 3(January), 810.

https://doi.org/https://doi.org/10.10 07/978-3-319-71084-6_36

Kraut, R. (2013). Policy guidelines for mobile learning. Unesco.

Mukuan, J. J. (2016). Speaking skills improvement though storytelling techniques using drawings as the media. Bahtera: Jurnal Pendidikan Bahasa Dan Sastra, 15(2), 71-82.

Mutalib, M. A., Abd Halim, N, D., \& Yahaya, N. (2012). A Review on Use of Social Media in Teaching and Learning, (2014), 11.

Nasution, M. I. P. (2016). Strategi Pembelajaran Efektif Berbasis Mobile Learning pada Sekolah Dasar. Jurnal Iqra, (V).

Noor-Ul-Amin, S. (2013). An Effective Use of ICT for Education and Learning by Drawing on Worldwide Knowledge, Research, and Experience. ICT as a Change Agent for Education. India: Department of Education, University of Kashmir.

Putrawangsa, S., \& Hasanah, U. (2018). Integrasi Teknologi Digital dalam Pembelajaran di Era Industri 4.0. Jurnal Tatsqif, 16(1), 42-54.

Ratminingsih, N. M. (2016). Efektivitas Media Audio Pembelajaran Bahasa Inggris Berbasis Lagu Kreasi di Kelas Lima Sekolah Dasar. JPI (Jurnal Pendidikan Indonesia), 5(1), 27-38.

Saleh, N., Saud, S., \& Asnur, M. N. A.
(2018). Pemanfaatan QR-Code sebagai media pembelajaran Bahasa Asing pada Perguruan Tinggi di Indonesia. In Seminar Nasional Dies Natalis UNM 57 (pp. 253-260).

Santyasa, I. W. (2007). Model-Model Pembelajaran Inovatif. Universitas Pendidikan Ganesha.

Saud, S., Saleh, N., \& Asnur, M. N. A. (2018). Dampak experiential learning dalam pembelajaran keterampilan berbicara bahasa Jerman mahasiswa di perguruan tinggi. In Seminar Nasional Dies Natalis UNM 57 (pp. 383-391).

Suryadi, A. (2007). Pemanfaatan ICT dalam Pembelajaran. Jurnal Pendidikan Terbuka Dan Jarak Jauh, 86.

Wael, A., Asnur, M. N. A., \& Ibrahim, I. (2018). Exploring Students' Learning Strategies in Speaking Performance. International Journal of Language Education, 2(1), 65. https://doi.org/10.26858/ijole.v2i1. 5238

Yanti, P. G., Amalia, N., \& Nawawi, N. (2018). Improving the debate ability though inquiry method and audio visual learning media in course of speaking skill. Bahtera: Jurnal Pendidikan Bahasa Dan Sastra, 17(2), 82-113.

Yusri, Rosida, A., Jufri, \& R, M. (2018). Efektivitas Penggunaan Media Youtube Berbasis Various Approaches dalam Meningkatkan Motivasi Belajar Bahasa Inggris. Eralingua, 2(2), 77-82. Retrieved from http://ojs.unm.ac.id/eralingua/articl e/view/6760/3868 